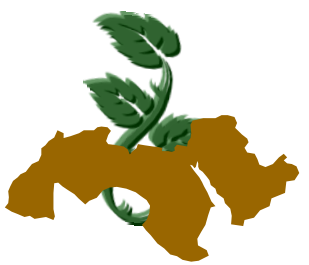

Arab Univ.

J. Agric. Sci., Ain Shams Univ., Cairo, 22(2), 381 - 394, 2014

\title{
INFLUENCE OF USING SOME SAFETY MATERIALS ON WATER REQUIREMENT AND WATER USE EFFICIENCY OF SNAP BEAN PLANT
}

\author{
Byan, Usrya ${ }^{1}$ A.I. \\ 1- Vegetable Res. Dept., Hort. Res. Inst., Agric. Res. Center, Giza, Egypt
}

Keywords: Snap bean, Safety materials, Water requirement, Water use efficiency, Class $A$ pan

\section{ABSTRACT}

Two field experiments were conducted during the two successive seasons of 2011/2012 at the Experimental Farm, Kaha station, Qulubia Governorate to study the effect of using four levels of water regime ,i.e. $60 \%, 80 \%, 100$ and $120 \%$ from class $\mathrm{A}$ pan evaporation and five safety materials, i.e. water (as control),amino-z, lithovit (a natural intensified $\mathrm{CO}_{2}$ foliar fertilizer ) as foliar spray on snap bean plants as well as the biofertilize mycorrhizal as a seed treatment before sowing and sap material as a absorbent polymer to increase with holding water capacity before sowing and the effect of that on growth, green snap bean yield Poulista $\mathrm{cv}$., physical and chemical characters as well as water use efficiency. The results indicated that, mycorrhizal seed treatment, lithovit foliar spray and soil treatment with sap material gave the highest values of green pod characters as well as the vegetative growth, in addition all the safety material used led to significant increment on pod yield and the favorable treatments were obtained by using sap material and foliar spray with amino -z. Concerning to using safety materials with water regime levels, it was found that, spraying snap bean plants with amino- $z$ and irrigation with $120 \%$ levels from class A pan evaporation was the superior treatment on green pod yield followed by soil treatment with sap material with $60 \%$ of water level. Regarding to the mean of green pod weight, the results showed that treating seed with mycorrhizal and $120 \%$ level of water regime gave the highest values during the two seasons, then the treatment of foliar spray with lithovite with $80 \%$ level of water regime and the treatment by sap soil treatments with supplied by $60 \%$ of water irrigation. Concerning to water use efficiency, the data showed that supplied the plants with the highest amount of water $120 \%$ and $100 \%$ from water irrigation decreased the values of water use efficiency, on the contrary, it can obtained the highest values of water use efficiency from water supplied with $60 \%$ then $80 \%$ calculated by class A pan evaporation method. Regarding to the effect of safety material on water use efficiency, it was found that, sap treatment or foliar spray with amino-z then, mycorrhizal treatments gave the highest value of water use efficiency. Generally, it can recommend by using sap material of soil addition before sowing and foliar spray by amino- $\mathrm{z}$ followed by treating the seeds with mycorrhizal with irrigation level $60 \%$ or $80 \%$ to obtained the favorable green pod yield and the favorable water use efficiency.

\section{INTRODUCTION}

Bean is considered one of the economic important vegetable crops in Egypt. It does not consume large amounts of fertilizer, plus it is consider short season crop, where as it produce green pod yield through short period after two months from sowing, as well as, it is one of the crops that cause soil fertility or neither consumes nor depletes soil nutrients. It's also one of the few vegetable crops that can be grown with particularly described it for either local consumption or exportation, moreover, the green pods or dry snap bean seeds contain cheap source from protein and carbohydrate.

There is a critical need to balance water availability, water requirements and water consumption thus water conserving is becoming a decisive consideration for agriculture, where water is the main limiting factor for plant growth. Moreover, plants are prodigal in the water use because only roughly $5 \%$ of water uptake is used for its growth and de- 
velopment while the remaining $95 \%$ is lost through transpiration and leaching (Prakash and Ramachandran, 2000). Evapotranspiration data for agricultural crops has become increasingly important in irrigation management as well as in water resources management. It is dependent not only on the meteorological elements, but also on factors related to the crop and to the soil availability and soil environment. Many authors have established general relationships between evapotranspiration and biomass production. However, Onder et al (2006). They added also that pod weight, length of plant significantly increased with increasing amount of water. In the experiment, pod width, length of pod increased with increasing amount of water. But such increases in these parameters were not significant, statistically. Moreover, they found also that increasing the amount of irrigation water resulted in a significant reduction in number of leaf per the plants. El-Gendy et al (2007) elucidated that the maximum yield of snap bean was obtained with the first treatment (100\% ETc) whenever the lower yield resulted from the third treatment (50\% ETc).Moreover, The irrigation at $\mathrm{I}_{100}$ level gave the highest green bean yield. Unirrigated treatment $\left(I_{0}\right)$ gave the lowest values for yield and yield parameters. Similar relationships between irrigation amount and bean yield were also reported by Ozekici (2001) reported no significant differences in yield quality between water amounts. Sezgin et al (2002) Mozumder et al (2005) and Sezen et al (2005), they illustrated that irrigation frequency and amount of applied water significantly affected some yield qualities. Mozumder et al (2005) reported that increase of irrigation amount increased plant height and pod yield. As observed by Castrillo et al (1990) and Karas (1997) on snap bean, protein content may show significant decrease under deficit, followed by an increase with addition of water. Moreover, Mahmoud (2000), Saleh and El-Tantawy (2001) on snap bean and Buan (2002) on pea and cowpea plants, found that values of water use efficiency were affected by two components; marketable yield and water applied.They added that maximum ETa values were detected at flowering stage and WUE increased remarkably as the water consumptive use increased.

Regarding to sap materials which contain polyacrylamide polymers, being the most popular polymeric conditioners, the anionic polyacrylamide polymers (PAMs) are water-soluble, have high molecular weight and low toxicity, with their moderate negative-charged chains stabilize soil aggre- gates by locculating clay particles (Sojka et al. 2007) modified crop soil management with PAM has shown great promise for soil erosion and water conservation (Walker et al. 2010). The application of PAMs could have positive effects on plant growth. The PAM application generally improves physical soil parameters such as hydraulic properties, infiltration rate, aeration, root penetration, and aggregate stability, thereby boosts plant establishment and growth rate (Flanagan et al. 2003). PAMs can also preserve plant-available water in soils so as to maintain sufficient soil moisture (Nadler and Steinberger 1993), thus increase water use efficiency and reduce water stress during drought events. Positive effects of PAMs on crop yields and growth activities can be found in Bjorneberg et al. (2003), Abu-Zreig et al. (2007) and Lentz and Sojka (2009). The effects of PAMs on plant growth may occur at two timescales. The shorter timescale includes the instantaneous processes of $\mathrm{CO} 2$ assimilation and respiration (Werth and Kuzyakov 2008). While the longer scale includes the accumulation of above and belowground biomass during the entire growth period, and actually represents the cumulative effects of the shorter process-related timescale.

Lithovit, a natural intensified $\mathrm{CO}_{2}$ foliar fertilizer for indoor/outdoor use, is a top-quality natural technological product created by tribodynamic activation and micronization to levels of $10-20 \mathrm{mi}-$ crons. Lithovit can considerably increase the photosynthesis rate, since one of the essential factors limiting photosynthesis outdoors is the lower natural $\mathrm{CO}_{2}$ content of the air. This leads to yield increases (up to $50 \%$ and more), accompanied by a reduced water requirement (by up to $75 \%$ ), and since with Lithovit, plants are able to keep the stomata closed longer time in case of water stress (balancing of nutrients). In addition, the micronutrients also contained in the product and the trace elements that influence plant physiology and increase the resistance against unfavorable weather condition and diseases, growth, vitality and general quality of the crop.

Regarding to amino zeid contain $85 \%$ amino acids, it is known that, amino acids as organic nitrogenous compounds stimulated cell growth acting as buffers maintaining favorable $\mathrm{pH}$ value within the plant cell as well as synthesizing other organic compounds, such as protein, amines, purines,pyrimidines, alkaloids, vitamins, enzymes, terpenoids and others (Goss, 1973).

Most plant species exploit the soil with the help of beneficial microorganisms called mycorrhizal 
fungi it can significantly increase water uptake by their host plants, and can provide a measurable degree of drought stress for plants grown under droughty conditions where irrigation is not available. Fields under reduction in water without irrigation can produce normal crop yields by applying mycorrhizal fungi inoculants. Moreover, it has been demonstrated that AM symbiosis affects the water relations of many plants. The AM symbiosis often results in the change of water movement into, through, and out of the host plants, with consequent effects on tissue hydration and plant physiology. The contribution of mycorrhizal symbiosis to drought tolerance is due to a combination of physical, nutritional, physiological, and cellular effects (Aroca et al 2008 and Miransari, 2010). Moreover, it can increase plant nutrient uptake, growth and yield quality (Cameron, 2010). Mycorrhiza offers several benefits to the host plant, including faster growth, improved nutrition and improved soil structure. Arbuscular mycorrhiza (AM) acts as a major conduit in principal elemental cycles (Fitter et al 2011). Mycorrhiza may especially enhance plant uptake of phosphors $(\mathrm{P})$, nitrogen $(\mathrm{N})$ and micro nutrients (Marschner and Dell, 1994).

However, this work was raised to elucidate the response of snap bean plants to some safety materials under different water regimes as well as the relationship between us on consumptive use (WCU), water use efficiency and its reflects on snap bean growth, pod yield and its quality.

\section{MATERIALS AND METHODS}

The present work was carried out during two successive seasons of 2011 and 2012 at the Experimental Farm, Kaha Station, Qalubia Governorate. Soil was clay in texture with $7.2 \mathrm{ph}, 3.5 \mathrm{EC}$ $1.15 \%$ organic matters, 110 ppm N, 49 ppm P and 103 ppm K. Seeds of snap bean cv. Poulista were obtained from Horticultural Research Institute, Agriculture Research Center, Egypt and sown on September $23^{\text {rd }}$ and $22^{\text {nd }}$ in 2011 and 2012, respectively. A split plot design system with three replicates was adopted. The seeds of snap bean were sown in hills on one side of ridges at $25 \mathrm{~cm}$ spaces. The area of each experimental plot was $2.4 \mathrm{~m}^{2}$ (4m long with $0.6 \mathrm{~m}$ width).

The experiment include twenty treatments, i.e., the combination among 4 irrigation levels, namely $60 \%, 80 \%, 100 \%$ and $120 \%$ from historical class A pan evaporation data (2010/2011 and 2011/2012) for Qalubia region, expressed as $\mathrm{mm} /$ day were distributed at random in main plots, five safety ma- terials as shown in Table (1), (water, Amino-z, Lithovit, Mycorrhizal and Sap) occupied the sub plots. Compounds (water, Amino-z and Lithovit) were used as foliar nutrition. Plants were sprayed three times with aqueous solution of the used materials, the first spray was conducted at the three true leaves stage, whereas the second and third spray were preformed 12 days intervals. Sap material was mixed with soil before sowing during soil preparation at $15 \mathrm{~cm}$ depth a rate of $8 \mathrm{~kg} / \mathrm{fed}$. While, the used of mycorrhizal was added a rate of $2 \mathrm{~kg}$ per fedan as a suspension and the seeds were treated with it before sowing:

Table 1. Names and contains of the materials used in this study

\begin{tabular}{|c|c|c|}
\hline $\begin{array}{c}\text { Compounds } \\
\text { name }\end{array}$ & Composition & Concentration \\
\hline Control & Distilled water & - \\
\hline Amino $-Z$ & $\begin{array}{c}85 \% \text { free amino } \\
\text { acids }+10 \% \text { organic } \\
\mathrm{N}+2.5 \% \mathrm{~K}_{2} \mathrm{O}\end{array}$ & $\begin{array}{c}0.5 \mathrm{~g} / \text { liter as } \\
\text { foliar spray }\end{array}$ \\
\hline Lithovit & $\begin{array}{c}80.2 \% \mathrm{Ca} \mathrm{Co}_{3} \\
4.6 \% \mathrm{Mg} \mathrm{Co}_{3} \\
0.2 \% \mathrm{~K}_{2} \mathrm{O}, 0.75 \% \\
\mathrm{Fe}\end{array}$ & $\begin{array}{l}1 \mathrm{~g} / \text { liter as } \\
\text { foliar spray }\end{array}$ \\
\hline Mycorrhizal & $\begin{array}{c}\text { Beneficial } \\
\text { microorganisms } \\
\text { called } \\
\text { Arbuscular } \\
\text { mycorrhizal fungi. }\end{array}$ & $\begin{array}{l}2 \mathrm{~kg} / \text { seeds/fed } \\
\text { mixed with } \\
\text { wilting seeds } \\
\text { before sowing }\end{array}$ \\
\hline Sap & Polyacrylamide & $\begin{array}{c}8 \mathrm{~kg} / \mathrm{fed} \text { mixed } \\
\text { with the soil of } \\
\text { ridges side of } \\
\text { sowing } \\
\end{array}$ \\
\hline
\end{tabular}

Water management measurements

Water management measurements were obtained and calculated according to the following equations according to Doorenbos and Pruitt (1977).

(1) $E T_{0}=\mathrm{Kp} \times$ Epan mm/day

Where:

$\mathrm{ET}_{0}=$ Potential evapotranspiration

$\mathrm{Kp}=$ Pan Coefficient $=0.85$

Epan $=$ Pan evaporation in $\mathrm{mm} /$ day

(2) $E T c=E T_{0} \times \mathrm{Kc} \mathrm{mm} /$ day

Where:

$\mathrm{ET}_{0}=$ the rate of evapotranspiration from an excessive surface of green cover of uniform height (8 to $15 \mathrm{~cm}$ ) actively growing, completely shading the ground and did not face shortage in water.

$K c=$ crop coefficient

ETcrop = the water requirement of a given crop in $\mathrm{mm}$ per unit of time e.g. $\mathrm{mm} /$ day, $\mathrm{mm} /$ month or $\mathrm{mm} /$ season. 
Table 2. Crop evapotranspiration (ETc) $\mathrm{mm}$ of snap bean plant at different levels of irrigation levels during 2011 and 2012 seasons

\begin{tabular}{|c|c|c|c|c|c|c|}
\hline \multirow{3}{*}{ Growth stages } & \multirow{3}{*}{ Days } & \multirow{3}{*}{$\begin{array}{c}\text { FAO } \\
\text { Kc }\end{array}$} & \multicolumn{4}{|c|}{ Crop evapotranspiration $\mathrm{mm}$} \\
\hline & & & \multicolumn{4}{|c|}{ Irrigation levels } \\
\hline & & & $60 \%$ & $80 \%$ & $100 \%$ & $120 \%$ \\
\hline \multicolumn{7}{|l|}{ First season } \\
\hline Initial & $20(19-39)$ & 0.5 & 8.60 & 11.47 & 14.34 & 17.20 \\
\hline Crop development & $30(39-69)$ & 0.8 & 21.95 & 29.27 & 36.59 & 43.90 \\
\hline Mid-season & 30 (69-99) & 1.1 & 28.77 & 38.37 & 47.96 & 57.55 \\
\hline Late season & $10(99-109)$ & 0.9 & 9.29 & 12.39 & 15.48 & 18.58 \\
\hline Seasonal & 90 & 0.8 & 68.61 & 91.5 & 114.37 & 137.23 \\
\hline \multicolumn{7}{|l|}{ Second season } \\
\hline Initial & $20(19-39)$ & 0.5 & 10.51 & 14.02 & 17.53 & 21.03 \\
\hline Crop development & $30(39-69)$ & 0.8 & 20.34 & 29.98 & 37.48 & 44.98 \\
\hline Mid-season & $30(69-99)$ & 1.1 & 28.39 & 37.86 & 47.33 & 56.79 \\
\hline Late season & $10(99-109)$ & 0.9 & 9.29 & 12.39 & 15.48 & 18.58 \\
\hline Seasonal & 90 & 0.8 & 68.53 & 94.25 & 117.82 & 141.38 \\
\hline
\end{tabular}

\section{Water Use Efficiency (WUE)}

Water use efficiency was calculated for different treatments using the following equation (Monteith, 1986)
WUE $=$ Total water consumption ( $\mathrm{m}^{3} /$ plant $)$

Table 3. The monthly average class $A$ pan evaporation $(\mathrm{mm})$ and temperature $\left({ }^{\circ} \mathrm{C}\right)$ during 2011/2012 and 2012/2013 seasons

\begin{tabular}{|c|c|c|c|c|c|c|}
\hline \multirow{3}{*}{ Months } & \multirow{3}{*}{$\begin{array}{c}\text { Class A pan } \\
\mathrm{mm}\end{array}$} & 201 & 12 & \multirow{3}{*}{$\begin{array}{c}\text { Class A pan } \\
\text { mm }\end{array}$} & \multirow{2}{*}{\multicolumn{2}{|c|}{$\begin{array}{c}\text { 2012/2013 } \\
\text { Temperature }\end{array}$}} \\
\hline & & \multicolumn{2}{|c|}{ Temperature } & & & \\
\hline & & Max. & Min & & Max. & Min. \\
\hline September & 4.1 & 31.7 & 16.3 & 4 & 36.7 & 14.7 \\
\hline October & 2.7 & 38.1 & 10.8 & 3.3 & 33.9 & 13.1 \\
\hline November & 2.1 & 25.0 & 5.8 & 1.9 & 29.9 & 6.9 \\
\hline December & 1.5 & 21.8 & 2.5 & 1.5 & 27.3 & 3.8 \\
\hline January & 1.8 & 21.9 & 1.5 & 1.8 & 24.8 & 1.7 \\
\hline
\end{tabular}

\section{Data Recorded}

\section{I- Plant Growth Measurements}

A representative sample of 3 plants was taken by random 55 days after sowing (flowering stage), from each experimental sub plot for measuring the plant growth characters, as follows:
Plant length $(\mathrm{cm})$, number of leaves, total fresh weight and dry weight of plant, determined at $65^{\circ} \mathrm{C}$ for 72 hours using the standard methods as illustrated by A.O.A.C (1990).

The leaf area was calculated according to the following formula of Wallace and Munger (1965):

Leaf area $\left(\mathrm{cm}^{2}\right)=$ Leaves dry weight $(\mathrm{gm}) \mathrm{x}$ disk area

Disk dry weight (gm) 


\section{II- Yield and Yield components}

A random sample of 10 green pods at the second picking 75 days after sowing from each sub plot were taken to determine the following data:

Average pod length $(\mathrm{cm})$, Pod diameter $(\mathrm{cm})$, Average fresh pod weight (g) - Average dry pod weight $(\mathrm{g})$ and Total pod yield ton/fed.

\section{III- Chemical properties}

Total leaf chlorophyll was measured using Minolta chlorophyll Meter SPAD- 501 as SPAD units. Total nitrogen, phosphorus and potassium were determined in dry pods on the basis of dry weight according to the methods described by Bremner and Mulvaney (1982); Olsen and Sommers (1982) and Jackson (1967), respectively.

Total protein \%: It was determined as nitrogen of pod content and converted to its equivalent protein content by multiplying $\mathrm{N}$ content* 6.25 (A.O.A.C.1990).

Total sugars. It was determined on the basis of pod dry matter, calorimetrically using spectrophotometer with the phenol sulphuric acid method described by Dubois et al (1956).

Statistical Analysis: All data were subjected to statistical analysis according to the procedures reported by Snedecor and Cochran (1982) using M. stat program and means were compared by L.S.D multiple range tests at the $5 \%$ level of probability in the two seasons of experimentation.

\section{RESULTS AND DISCUTION}

\section{I- Effect of water regime, safety materials on vegetative growth}

\section{I.1 Effect of water regime levels}

The vegetative growth parameters of snap bean plants, i.e., plant length, number of leaves/plant, leaf area as well as the fresh and dry weight of plant as affected by irrigation levels and some safety materials are shown in Table (4). The data reveal that irrigation regime did not exert significant effect on plant length in both growing season in spite of the $100 \%$ and $120 \%$ irrigation showed obvious increment in plant length and number of leaves compared to $60 \%$ or $80 \%$. Meanwhile, the differences between treatments reached to the level of significance in the first season for number of leaves. The abundance of water under $100 \%$ and 120 of class A pan encouraged the meristematic activity and hence the length of plants. The greatest number of leaves was found on the tallest plants where the abundance of water under $100 \%$ and $120 \%$ of class A pan promoted the meristematic activity then led to increasing the length of plant and hence, number of leaves.

Leaf area, plant fresh as well as dry weights of $120 \%$ treatment were the highest value compared to the other treatments in both seasons. The highest value of plant length, the greatest number of leaves per plant and the highest values of leaf area due to $120 \%$ class A pan might enable to plants intercept and synthesize more metabolites than plants supplied by $100 \%, 80 \%$ or $60 \%$ treatments which might be reflected on the fresh and dry weight of the plants. These results are in the same line with those obtained by Buan (2002) on fabaceae crops, Sezgin et al (2002) Mozumder et al (2005), Sezen et al (2005) and Onder et al (2006) on snap bean.

\section{I.2 Effect of safety materials}

As shown in Table (4), snap bean plants grown from seeds treated with mycorrhizal, sprayed with lithovit and grown in the soil treated with sap materials gave the highest values of vegetative growth parameters, i.e., plant length, number of leaves/ plant, leaf area as well as the fresh and dry weight of plant. This was true in both growing season. These results may be due to Mycorrhiza offers several benefits to the host plant, including faster growth, improved nutrition and acts as a major conduit in principal elemental cycles (Fitter et al 2011). It can increase plant nutrient uptake especially $\mathrm{P}$ and N (Marschner and Dell 1994).

Concerning to lithovit, it is a natural intensified $\mathrm{CO}_{2}$ foliar fertilizer can considerably increase the photosynthesis rate. In addition, the micronutrients also contained in the product and the trace elements that influence plant physiology and increase growth.

The application of sap material which contain the anionic polyacrylamide polymers (PAMs). PAMs could have positive effects on plant growth Flanagan et al 2003) Bjorneberg et al (2003), Abu-Zreig et al (2007) and Lentz and Sojka (2009). The effects of PAMs on plant growth may occur at two timescales. The shorter timescale includes the instantaneous processes of $\mathrm{CO}_{2}$ assimilation and respiration (Werth and Kuzyakov 2008). While the longer scale includes the accumulation of above and below-ground biomass during the entire growth period, and actually represents the cumulative effects of the shorter processrelated timescale. 
Arab Univ. J. Agric. Sci., 22(2), 2014 


\section{I.3 Effect of the interaction between water regime levels and safety materials on vegetative growth}

The results of the interaction effect between irrigation levels and safety materials on vegetative growth, i.e., plant length, number of leaves, leaf area and fresh as well as dry weight of snap bean plant are shown in Table (4). It is obvious that plants treated with mycorrhizal and supplied by $120 \%$ of irrigation water gave the highest values of all vegetative growth parameters except plant length and leaf area, data revealed also that sap material and supplied snap bean plants by $120 \%$ of irrigation water gave the highest values of all vegetative growth.

II- Effect of water regime levels, safety materials on yield and yield components

\section{II.1 Effect of water regime levels}

Data in Table (5) show that, there is no significant effect from using all irrigation treatments on pod length or pod diameter in both growing seasons and fresh pod weight in the second season while in the first seasons the highest values of fresh pod weight were obtained from using $60 \%$ and $80 \%$ followed by $120 \%$ of the calculated amount of water treatments. On the other hand, plants irrigated with $120 \%$ treatment gave the highest pod yield in both growing seasons. These results are agreement with the results of Ozekici (2001) and Onder et al (2006) on green bean which they reported that no significant differences in yield quality due to water amounts. Similar relationships between irrigation amount and bean yield were also reported by Sezgin et al (2002) Mozumder et al (2005) and Sezen et al (2005).

\section{II.2 Effect of safety materials}

Yield and yield attributes of snap bean showed significant results by using different safety materials as shown in Table (5). The data showed that the plants treated with mycorrhizal, lithovit followed by sap materials exerted the highest values of pod length and fresh pod weight in both growing seasons but the differences did not reach to significance level in the second season for pod diameter. On the contrary, Mycorrhiza offers several benefits to the host plant, including faster growth, improved nutrition and improved soil structure. Arbuscular mycorrhiza (AM) acts as a major conduit in principal elemental cycles (Fitter et al 2011). It can increase plant nutrient uptake and yield quality as mentioned by (Cameron 2010).concerning to lithovit, the micro-nutrients contained in the product and the trace elements that influence plant physiology and increase the resistance against the different stresses, growth, vitality and general quality of the crop. Moreover, pod yield was significantly increased by all safety materials treatments. In this respect, using sap material and spraying plants with amino-z were the best effective treatments on snap bean yield in both growing seasons. This increase is due to positive effects of PAMs and amino acids on crop yields and growth activities which can be found in Bjorneberg et al. (2003), Abu-Zreig et al. (2007) and Lentz and Sojka (2009).

\section{II.3 Effect of the interaction between water regime levels and safety materials on yield and yield components}

The response of snap bean yield and yield attributes to the interaction effect among irrigation water quantity and safety materials are shown in Table (5). The results revealed that the highest values of pod length was obtained from plants sprayed with lithovit compound and supplied by $80 \%$ of water irrigation in the second season but the increase failed to reach the significant in the first season. Moreover, pod yield increased significantly in the first season. In this respect, using sap material and spraying plants with amino-z and supplied by $120 \%$ of water irrigation followed by using sap material with $60 \%$ of water irrigation were the best effective treatments on snap bean yield. Concerning fresh pod weight, data showed that the plants treated with mycorrhizal and supplied by $120 \%$ of water irrigation gave the highest values in both growing seasons followed by plants treated with lithovit and supplied by $80 \%$ of water irrigation and sap material with $60 \%$ of water irrigation, respectively. While, pod diameter showed non-significant differences between irrigation water quantity and safety materials in both growing season.

\section{III- Effect of water regime, safety materials on chemical properties}

\section{III.1 Effect of water regime levels}

Data in Table (6) show the influence of irrigation levels on chemical properties of snap bean seeds, i.e., total sugars, protein percentage, N\%, P\%, K\% as well as total chlorophyll of leaves. It was found that the plants supplied with $60 \%$ or $80 \%$ of water 
calculated by class A pan produced pods containing the highest values of total sugars $\%$ and $\mathrm{K} \%$ compared with those supplied by higher a mounts of water $(100 \%$ or $120 \%)$. These results are in agreement with those obtained by Adams (1990) on tomato, who found that restricting water to $60 \%$ and $80 \%$ of the water requirement increased potassium concentration in the fresh organs of tomato. While, Plants supplied by $120 \%$ of the class A pan records, showed higher concentration of $\mathrm{P} \%$ in its pods than those supplied by other treatments. These results may be due to abundance of water quantities encouraged the absorption of minerals and its translocation to leaves. Alam (1999) reported that, Water stress may affect the mineralnutrient relations in plants. Generally, drought reduces both nutrient uptakes by the roots and transport from the roots to the shoots, because of restricted transpiration rates and impaired active transport and membrane permeability.

Regarding the effect of irrigation water quantity on leaf chlorophyll contents, data in Table (6) revealed that plants supplied by $120 \%$ of water calculated by class A pan showed the lowest concentration of chlorophyll in the leaves than those supplied by less amounts of water $(60 \%, 80 \%$ or $100 \%)$. The results are true in both growing seasons. The reduction in moisture content in tissues of plants supplied by less amount of water may owe much to such observation. It is worth to mention that the leaf area of snap bean plants was increased as the amount of irrigation water increased (Table, 4) and this might compensate much for the reduction in the chlorophyll content in the leaves under the treatments of high irrigation levels. In this connection Mahamoud (2000) on pea, Buan (2002) on pea and cowpea and ElMogy et al. (2012) on pea, they found that irrigation levels significantly affected on total chlorophyll contents in plant leaves. Thus, the low level of irrigation levels increased the concentration of total chlorophyll.

\section{III.2 Effect of safety materials}

As shown in Table (6) using mycorrhizal for snap bean plants as seeds treatment before sowing gave the highest concentration of pod total sugars in both growing season. Moreover, mycorrhizal and sap materials were the best treatments for $\mathrm{P} \%$ these results are agreement with the results showed by(Marschner and Dell 1994) they reported that mycorrhiza may especially enhance plant uptake of phosphors $(\mathrm{P})$, nitrogen $(\mathrm{N})$ and micro nutrients. Moreover, it can increase plant nutrient uptake (Cameron 2010) and acts as a major conduit in principal elemental cycles (Fitter et al 2011)

Concerning to the effect of amino $z$, it was found that, the plants sprayed with amino-z compound gave pods contain high concentration of $\mathrm{K}$ and high concentration of chlorophyll in the leaves, these result may due to chemical structure of amino zeid, which contain $85 \%$ amino acids, it is known that, Amino acids as organic nitrogenous compounds stimulated cell growth. (Goss, 1973).

\section{III.3 Effect of the interaction between water regime levels and safety materials on chemical properties}

Effect of the interaction between irrigation levels and safety materials on chemical properties, total sugars, total protein, N, P, K\% in snap bean pod and chlorophyll in the leaves are shown in Table (6). It is obvious that plants sprayed with amino-z and supplied by $80 \%$ of irrigation water gave the highest values of chlorophyll in the leaves in the first season but in the second season the increase was non significant. While, plant treated with mycorrhizal and supplied by 60 or $80 \%$ of irrigation water gave the highest values of pod total sugars $\%$ in the first season and second season, respectively. On the other hand irrigation with $120 \%$ and using sap material showed the highest concentration of $\mathrm{P} \%$ this was true in both growing season. Moreover, spraying amino- $z$ compound and supplied by $60 \%$ of irrigation water gave the highest values of $\mathrm{K} \%$ in two seasons.

\section{I.V Water Use Efficiency (WUE)}

Water use efficiency of snap bean plants at different levels of irrigation and safety materials is shown in Table (7). Data revealed that water use efficiency decreased as the amount of irrigation water increased to $100 \%$ or $120 \%$ level of pan method and the highest values were obtained from $60 \%$ treatment followed by $80 \%$ of water calculated by class A pan evaporation method. This was true in both growing season. The reduction in WUE by the increasing the amount of irrigation water to the levels of $100 \%$ or $120 \%$ pan method might be due to the increasing in snap bean water consumption use (WCU) as shown in Table (7).

In this connection, Mahmoud (2000), Saleh and El-Tantawy (2001) on snap bean and Buan (2002) on pea and cowpea plants, found that water use efficiency was decreased at the high level of irrigation levels. 
Table 7. Water consumption use (WCU) and water use efficiency (WUE) of snap bean plant at different levels of irrigation levels and safety materials during 2011 and 2012 seasons

\begin{tabular}{|l|c|c|c|c|c|c|}
\hline \multirow{2}{*}{ Treatments } & \multicolumn{3}{c|}{ First season } & \multicolumn{3}{c|}{ Second season } \\
\cline { 2 - 7 } & $\begin{array}{c}\text { Yield } \\
\text { Kg/fed }\end{array}$ & $\begin{array}{c}\text { Total WCU } \\
\mathbf{m}^{3} / \mathbf{f e d}\end{array}$ & $\begin{array}{c}\text { WUE } \\
\mathbf{K g} / \mathbf{m}^{3}\end{array}$ & $\begin{array}{c}\text { Yield } \\
\mathbf{K g} / \mathbf{f e d}\end{array}$ & $\begin{array}{c}\text { Total WCU } \\
\mathbf{m}^{3} / \mathbf{f e d}\end{array}$ & $\begin{array}{c}\text { WUE } \\
\mathbf{K g} / \mathbf{m}^{\mathbf{3}}\end{array}$ \\
\hline I. Irrigation (\%) from class A pan & & & & & & \\
$\mathbf{6 0 \%}$ & & & & & & \\
$\mathbf{8 0} \%$ & 3840 & 274.51 & 13.98 & 3640 & 274.22 & 13.27 \\
$\mathbf{1 0 0} \%$ & 4100 & 366.01 & 11.20 & 3700 & 377.05 & 9.81 \\
$\mathbf{1 2 0} \%$ & 3580 & 457.53 & 7.82 & 3380 & 471.34 & 7.17 \\
& 4520 & 549.00 & 8.23 & 4700 & 565.60 & 8.30 \\
II. Safety materials & & & & & & \\
& & & & & & \\
Water & 2620 & 411.76 & 6.36 & 2780 & 422.05 & 6.58 \\
Amino-Z & 4900 & 411.76 & 11.90 & 4610 & 422.05 & 10.92 \\
Lithovit & 3780 & 411.76 & 9.18 & 3340 & 422.05 & 7.91 \\
Mycorrhizal & 3920 & 411.76 & 9.52 & 3530 & 422.05 & 8.36 \\
Sap & 4820 & 411.76 & 11.70 & 5020 & 422.05 & 11.89 \\
\hline
\end{tabular}

Regarding water use efficiency (WUE) for snap bean plants treated with the materials used in this study, data in Table (7) show that plants treated with sap ,amino-z followed by mycorrhizal elucidated the highest values of WUE in the first season as well as in the second season. The increasing in WUE by using sap, amino-z or mycorrhizal might be due to the increasing in total yield of snap bean plants as shown in Table (4). In this regard, several investigators reported that values of WUE were affected by two components, i.e., marketable yield and water applied (Saleh and El-Tantawy, 2001). Moreover, concerning sap material which contain PAMs can also preserve plant-available water in soils so as to maintain sufficient soil moisture (Nadler and Steinberger 1993), thus increase water use efficiency and reduce water stress during drought events.

Generally, it can recommend by using sap material of soil addition before sowing and foliar spray by amino- $z$ followed by treating the seeds with mycorrhizal with irrigation level $60 \%$ or $80 \%$ to obtained the favorable green pod yield and the favorable water use efficiency.

\section{REFERANCES}

Abu-Zreig, M., M. Al-Sharif and J. Amayreh 2007. Erosion control of arid land in Jordan with two anionic polyacrylamides. Arid Land Res Manag 21: 315-328.
Adams, P. 1990. Effect of watering on the yield quality and composition of tomatoes grown in bags of peat .J. Hort . Sci .65(6): 667-674.

Alam, S.M. 1999. Nutrient uptake by plants under stress conditions. Handbook of Plant and Crop Stress. Marcel Dekker, New York, USA, pp. 285-314.

A.O.A.C. 1990. Official Methods of Analysis of Association of Official Agricultural Chemists. $15^{\text {th }}$ pp. 1045-1106.

Aroca, R., M. Alguacil, P. Vernieri and J.M. Ruiz-Lozano 2008. Plant responses to drought stress and exogenous ABA application are modulated differently by mycorrhization in tomato and an ABA-deficient mutant (Sitiens). Microbial Ecology, 56: 704-719.

Bjorneberg, D.L, F.L. Santos, N.S. Castanheira, O.C. Martins, J.L. Reis, J.K. Aase and R.E. Sojka 2003. Using polyacrylamide with sprinkler irrigation to improve infiltration. J. Soil Water Conserv. 58: 283-289.

Bremner, J.M. and C.S. Mulvaney 1982. Total nitrogen. In: Pag, A.L., R.H. Miller and D.R. Keeny (Eds). Methods of soil analysis. Part 2, Amer. Soc. Agron. Madison, W.I. USA, pp. 595-624.

Buan, Usrya, A. 2002. Studies on water requirement of some fabaceae crops. M.Sc. Thesis, Fac. Agric., Ain Shams Univ, Cairo, Egypt.

Cameron, D.D. 2010. Arbuscular mycorrhizal fungi as ecosystem engineers .Plant Soil, 333: 1-5. 
Castrillo, M., D. Fernandez, B. Molina and A. Kazandjian 1990. Metabolism of Phaseolus vulgaris $L$. under deficit water. Tunialba. 40(4): 515-519.

Doorenbos, J. and W.O. Pruitt 1977. Guidelines for predicting crop water requirements. FAO irrigation and drainage paper, FAO, ROM, NO. 24, pp. 30.

Dubois, M., A. Gilles, K.J. Hamihon, P.R. Rebers and P.A. Smith 1956. Achlorimetric methods substances. Anal. Chem., 28: 350.

El-Gendy, R.W., A.M. Gadalla, A. Hamdy, M. El-Moniem and A. Fahmy 2007. Irrigation water saving via scheduling irrigation of snap bean and direction of soil water movement under drip irrigation system. Water Saving in Mediterranean Agriculture and Future Research Needs., 1: 235-247.

El-Mogy, M.M., M.E. Abuarab and A.L. Abdullatif 2012. Response of green bean to pulse surface drip irrigation. J. Hort. Sci. and Ornamental Plants 4(3): 329-334.

Flanagan, D.C., L.D. Norton, J.R. Peterson, K. Chaudhari 2003. Using polyacrylamide to control erosion on agricultural and disturbed soils in rainfed areas: advances in the use of polyacrylamide (PAM) for soil and water management. J. Soil Water Conserv 58: 301-311.

Fitter, A.H., T. Helgason and A. Hodge 2011. Nutritional exchanges in the arbuscular mycorrhizal symbiosis implications for sustainable agriculture.Trends Cell Biol. 25: 68-72.

Goss, J.A. 1973. Amino acid synthesis and metabolism. In: New York. Physiology of Plant and their Cells. Pergamon Press, Inc., New York, USA, pp. 68-75.

Jackson, M.L. 1967. Soil chemical analysis. Prentic-Hall, India, Private Limited, New Delhi.

Karas, A.N. 1997. Effect of sowing dates and water stress on productivity of bean (Phaseolus ulgaris L.) plants. M.Sc. thesis. Faculty of Agriculture, Ain Shams Univ., Cairo, Egypt, $150 \mathrm{p}$.

Lentz, R.D and R.E. Sojka 2009. Long-term polyacrylamide formulation effects on soil erosion, water infiltration, and yields of furrow-irrigated crops. Agron. J. 101: 305-314.

Mahmoud, M.S.M. 2000. Effect of irrigation on growth and yield of pea plants (Pisum sativum L). M.Sc. Thesis, Fac. Agric., Minufiya Univ., Sheben El-Kome, Egypt. pp. 99-101.

Marschner, H. and B. Dell 1994. Nutrient uptake in mycorrhizal symbiosis. Plant Soil, 159:89102.
Miransari, M. 2010. Contribution of arbuscular mycorrhizal symbiosis to plant growth under different types of soil stress. Plant Biology, 12: 563-569.

Monteith, J.L. 1986. How do crops manipulate water supply and demand. Philosophical Transaction of the Royal Society, London. 316: 245-259.

Mozumder, S.N., M. Moniruzzaman, M.R. Islam, S.M. Faisal and M.A.R. Sarkar 2005. Effect of irrigation and mulch on bushbean production in the hill valley. Asian. J. Plant Sci., 4: 275-278.

Nadler, A. and Y. Steinberger 1993.Trends in structure, plant growth, and microorganism interrelations in the soil. Soil. Sci., 155:114-122.

Olsen, S. R. and L.E.Sommers 1982. Phosphorus. In: Page, A. L.; R. H. Miller and D. R. Keeney (Eds). Methods of Soil Analysis. Part 2 Amer. Soc. Agron. Madison, W.I. USA, pp. 403-430.

Onder, S., S. Bozkurt, G. Sayilikan, D. Onder and M. Kara 2006. Effects of water stress and mulch on green bean yield and yield components in greenhouse condition. Asian. J. of Plant Sci., 5: 127-132.

Ozekici, B. 2001. Effect of different irrigation levels on the yield and quality of snap beans grown in greenhouses. Cukurova University Research Project. Final Report, 7 p.

Prakash, M. and K. Ramachandran 2000. Effects of chemical ameliorants in brinjal (Solanum melongena L.) under moisture stress conditions. J. Agron. Crop Sci., 185: 237-239.

Saleh, M.M. and Manal, M. El-Tantawy 2001. Water requirements and leching ratio for snap bean production under clear polyethelene low tunnels. J. Agric. Sci. Mansoura Univ., Mansoura, Egypt 26(5): 3261-3270.

Sezen, S.M., A. Yazar, M. Canbolat, S. Eker and G. Celikel 2005. Effect of drip irrigation management on yield and quality of field grown green beans. Agric. Water Manage., 71: 243255.

Sezgin, F., T. Bas, E. Yilmaz and N. Dagdelen 2002. Determination of suitable irrigation program on green bean under plastic covering. Proceedings of the $4^{\text {th }}$ Vegetable Culture Symposium, Uludag University, 42 p.

Snedecor, C.W. and W.G. Cochran 1982. Statistical Methods. $7^{\text {th }}$ Ed. The lowa State Univ. Press. Ames. lowa, USA, pp. 325-330.

Sojka, R.E., D.L. Bjorneberg, J.A. Entry, R.D. Lentzq and W.J. Orts 2007. Polyacrylamide in 
agriculture and environmental land management. Adv. Agron. 92: 75-162.

Walker, P.M., C.A. Wade and T.R. Kelley 2010. Evaluation of a polyacrylamide assisted solid/ liquid separation system for the treatment of liquid pig manure. Biosyst Eng., 105: 241246.
Wallace, D.H. and H.M. Munger 1965. Studies of the physiological basis for yield differences. 1. growth and analysis of six dry bean varieties. Crop Sci., 5: 343-348.

Werth, M. and Y. Kuzyakov 2008. Root-derived carbon in soil respiration and microbial biomass determined by C-14 and C-13. Soil Biol Biochem 40: 625-637. 